\title{
INSTITUTE OF ADVANCED LEGAL STUDIES
}

\section{HOW ARD DRAKE MEMORIAL FUND}

7 HE FUnd was established in 1978 as a permanent memorial to Howard

1 Drake, Secretary and Librarian of the Institute of Advanced Legal Studies from 1947 to his death in 1967.

The objects of the Fund are as follows:

I. To encourage collaboration and exchanges between legal scholars and law librarians and especially between those of different countries;

2. to promote the study of law librarianship and the training of law librarians;

3. to do all such acts and things as may be expedient to further the above objects, whether by the provision of scholarships, fellowships, travel grants, and other financial assistance, the publication of books and papers, and the organisation of exchange visits, meetings, conferences, study groups and seminars, or otherwise.

Awards may be made at any time of the year and there is no fixed date for applications, which should be addressed to:

The Administrative Secretary

Institute of Advanced Legal Studies

Charles Clore House

I7 Russell Square

London WCiB ${ }_{5} \mathrm{DR}$

Tel: 447 I 637 I 73 I

Fax: 44715809613 